\title{
Endurskoðun laga um stjórn fiskveiða og jafnræðisregla stjórnarskrárinnar - vandratað er meðalhófið!
}

\author{
Kristín Haraldsdóttir, sérfræðingur, lagadeild Háskólans í Reykjavík
}

\begin{abstract}
Ágrip
Í greininni er fjallað um svigrúm löggjafans skv. jafnræðisreglu 65. gr. stjskr. og atvinnufrelsisákvæði 75. gr. stjskr. til að setja reglur sem veita afmörkuðum hópi heimildir til veiða úr nytjastofnum sjávar. Dómar Hæstaréttar sem petta snerta eru skoðaðir út frá sjónarmiðum um meðalhóf og sú ályktun dregin að hagsmunir pjóðarheildarinnar af verndun og hagkvæmri nýtingu vegi pungt í meðalhófsmatinu. Gerð sé krafa um að löggjafinn færi skýr rök fyrir pví að sú leið sem er valin sé í eðlilegu samhengi við hagsmuni pjóðarheildarinnar af verndun og hagkvæmri nýtingu fiskistofna. Fjallað er um frumvarp til laga um stjórn fiskveiða sem lagt var fram á síðastliðnu löggjafarpingi í pessu ljósi og bent á atriði sem kunna að orka tvímælis út frá framangreindum sjónarmiðum.
\end{abstract}

\begin{abstract}
The article discusses the margin of appreciation of the legislator under Article 65 of the Icelandic Constitution on equal rights when applied in relation to the right to engage in fishing protected under Article 75 of the Constitution on freedom of employment. Based on that discussion a bill of law on fisheries management presented in the Althingi in spring 2012 is analysed. It is submitted that the margin of appreciation is limited by fundamental obligations of the State to ensure that fishing resources are protected and utilized in the interest of the nation as a whole and that it is arguable whether certain aspects of the regime proposed in the bill are in confirmity with the Constitutional provisions.
\end{abstract}




\section{Inngangur}

Stjórnkerfi fiskveiða hefur verið til endurskoðunar í nokkur ár og birtist afrakstur peirrar vinnu m.a. í frumvarpi til laga um stjórn fiskveiða sem lagt var fram á síðasta pingi en hlaut ekki afgreiðslu (Pingskjal 1052, 2011-2012). Í frumvarpinu var gert ráð fyrir að fiskveiðum yrði áfram stjórnað með aflamarkskerfi en að á pví yrðu gerðar verulegar breytingar. Pannig var m.a. gert ráð fyrir að nýtingarrétturinn yrði tímabundinn og verulegar skorður settar við framsali veiðiheimilda. Með peim breytingum sem lagðar voru til á gildandi kerfi ótímabundinna og framseljanlegra veiðiheimilda átti m.a. að stuðla að auknu jafnræði og nýliðun í fiskveiðum (Pingskjal 1052, 2011-2012, athugasemdir, kafli 3.3). Í greininni eru tillögur frumvarpsins um breytingar á aflamarkskerfinu skoðaðar í ljósi jafnræðisreglu 65. gr. stjskr. og jafnræðissjónarmiða 75. gr. stjskr. Niðurstaða í dómum Hæstaréttar er snerta jafnræði til fiskveiða hefur ráðist af mati á meðalhófi. Pessir dómar eru rýndir og kannað sérstaklega hvaða leiðsögn peir veita um svigrúm löggjafans við útfærslu á aflamarkskerfi. Spyrja má hvort ekki sé augljóst að fyrst gildandi kerfi samræmist áðurnefndum greinum stjórnarskrárinnar (sbr. Hrd. í máli nr. 12/2000 (Vatneyrardómur)1) pá hljóti breytingar sem eiga að koma til móts við kröfur um aukið jafnræði til veiða að gera pað einnig. Færð eru rök fyrir pví að svarið við pessari spurningu sé ekki augljóst og kunni jafnvel að vera neikvætt. Til einföldunar er umfjöllunin afmörkuð við stjórnun veiða innan íslenskrar fiskveiðilögsögu og eingöngu fjallað um pær reglur sem gilda áttu skv. frumvarpinu um stærri skip (15 brúttótonn eða stærri). Svonefnt krókaflamarkskerfi fellur pví utan umfjöllunarinnar.

\section{Um atvinnufrelsi og jafnræðisreglu íslenskrar stjórnskipunar.}

\subsection{Almennt}

Sú hugmynd að fiskveiðar séu frjálsar öllum utan netlaga á sér djúpar rætur í íslenskum rétti. ${ }^{2}$ Frelsi manna til fiskveiða hefur verið lýst sem almannarétti sem njóti takmarkaðrar réttarverndar og pví verið hafnað að pað njóti stjórnskipulegrar verndar sem eign í skilningi 72. gr. stjskr (Gaukur Jörundsson, 1969, bls. 79-81). Hins vegar er almennt viðurkennt að peir sem hafa nýtt sér frelsi til veiða og stunda fiskveiðar kunni að hafa áunnið sér atvinnutengd réttindi sem geta notið verndar 72. gr. stjskr., (um samantekt á peim sjónarmiðum sjá Guðrún Gauksdóttir, 2006, bls. 250). Pá hefur verið bent á að réttindi peirra sem ráða yfir ótímabundnum framseljanlegum aflahlutdeildum sem úthlutað hefur verið á grundvelli laga um stjórn fiskveiða nr. 116/2006³ kunni að njóta verndar 72. gr. stjskr. sem eign (Guðrún Gauksdóttir, 2006, 273). Á sama tíma er ljóst að 75. gr. stjskr. verndar frelsi manna til að velja

\footnotetext{
${ }^{1}$ Sbr. einnig dómur Hæstaréttar í Fagramúlamálinu (Hrd. í máli nr. 473/2002).

${ }^{2}$ Pannig sagði í Landbrigðispætti Grágásar og 2. kapitula rekabálks Jónsbókar að allir menn ættu veiði fyrir utan netlög að ósekju. Regla Jónsbókar er enn gildandi lög á Íslandi <http://www.althingi.is/lagas/nuna/lagas.nr.html\#1900>, sótt 23. ágúst 2012.

${ }^{3}$ Lög um stjórn fiskveiða nr. 38/1990 voru endurútgefin með lögum nr. 116/2006.
} 
atvinnu og stunda hana, p.á.m. fiskveiðar. Frelsinu má pó setja skorður með lögum, enda krefjist almannahagsmunir pess.

Takmarkanir á heimildum til veiða geta samkvæmt framansögðu fallið undir bæði 72. og 75. gr. stjskr. pegar slíkar takmarkanir snerta pá sem pegar stunda veiðar. Pær takmarkanir sem snúa að frelsi annarra til að hefja veiðar falla hins vegar eingöngu undir 75. gr. stjskr.

Umfjöllun greinarinnar er afmörkuð við síðarnefnd tilvik.

\subsection{Um atvinnufrelsi skv. 75. gr. stjskr.}

Samkvæmt 75. gr. stjskr. er öllum frjálst að stunda pá atvinnu sem peir kjósa. Frelsinu má pó setja skorður með lögum, enda krefjist almannahagsmunir pess. Af dómum Hæstaréttar sem snerta stjórn fiskveiða má ráða að löggjafinn hefur víðtækar heimildir til að grípa til almennra takmarkana til að tryggja verndun og hagkvæma nýtingu fiskistofna. Dómur Hæstaréttar í Vatneyrarmálinu er skýr hvað petta varðar. Par kom fram að 3. gr. laga nr. 38/1990 um ákvörðun heildarafla í einstökum tegundum samræmdist 75. gr. stjskr. um atvinnufrelsi. Dómurinn tók fram að ríkir almannahagsmunir væru bundnir við verndun og hagkvæma nýtingu fiskistofna á Íslandsmiðum og vísaði einnig til pjóðréttarskuldbindinga Íslands skv. Hafréttarsáttmálanum um að tryggja verndun og skynsamlega nýtingu fiskistofna. Рað var mat dómsins að aflatakmarkanir væri nauðsynlegur páttur í verndun og skynsamlegri nýtingu fiskstofna. Afdráttarlaust orðalag og að pví er virðist sjálfstætt mat á mikilvægi almannahagsmunanna og nauðsyn aflatakmarkana gefur til kynna að löggjafanum sé ekki aðeins heimilt heldur beinilínis skylt að takmarka frelsi til veiða til að tryggja verndun og hagkvæma nýtingu fiskistofna.

\subsection{Um jafnræðisreglu 65. gr. stjskr. í tengslum við 75. gr. stjskr.}

pær skorður sem löggjafinn reisir við atvinnufrelsi verða að samræmast sjónarmiðum um jafnræði sem ákvæðið byggir á og jafnræðisreglu 65. gr. stjskr. (sjá nánar Björg Thorarensen, 2008, bls. 527-532).

Samkvæmt jafnræðisreglu 1. mgr. 65. gr. stjskr., sbr. 3. gr. stjórnarskipunarlaga nr. 97/1995, skulu allir vera jafnir fyrir lögum og njóta mannréttinda án tillits til kynferðis, trúarbragða, skoðana, pjóðernisuppruna, kynpáttar, litarháttar, efnahags, ætternis og stöðu að öðru leyti. Almennt má segja að krafa 1. mgr. 65. gr. um jafnræði feli í sér að peir sem eru í sömu stöðu skuli fá sömu meðferð og peir sem eru í ólíkri stöðu skuli fá ólíka meðferð. Reglan felur ekki í sér óskilyrt bann við hvers konar greinarmun manna á milli. Greinarmunur getur verið réttlætanlegur, jafnvel pótt hann miðist við pau atriði sem tiltekin eru sérstaklega í ákvæðinu, ef hann byggist á hlutlægum og málefnalegum sjónarmiðum (Pingskjal 389, 19941995 og Páll Hreinsson, 2002, bls. 344-346). •að er háð mati hverju sinni hvort svo sé og dómstólum falið mikið vald í peim efnum (Páll Hreinsson, 2002, bls. 346).

Jafnræðisregla 1. mgr. 65. gr. stjskr. hefur efnislega samsvörun í 26. gr. Alpjóðasamningsins um borgaraleg og stjórnmálaleg réttindi (SBSR) og 14. gr. Mannréttindasáttmála Evrópu (MSE), sem lögfestur var hér á landi með lögum nr. 62/1994 (Pingskjal 389, 1994-1995, 
athugasemdir við 3. gr.). Gildissvið 14. gr. MSE er hins vegar prengra en 65. gr. stjskr. og 26. gr. SBSR par sem pað er bundið við pau réttindi sem MSE verndar. Atvinnufrelsi er ekki meðal peirra og pví hæpið að ákvæðið eigi við um takmarkanir á frelsi til veiða (sjá einnig Oddný Mjöll Arnardóttir, 2000, bls. 276). Dómar Mannréttindadómstóls Evrópu (MDE) er varða 14. gr. MSE hafa pó almenna pýðingu við skýringu 65. gr. stjskr. par sem Hæstiréttur virðist beita svipaðri greiningaraðferð og MDE við mat á pví hvort um sé að ræða ólögmæta mismunun (Oddný Mjöll Arnardóttir, 2005, bls. 461-467 og 471-472 og Björg Thorarensen, 2008, 568-571 og 582-591).

Fyrsta úrlausnaratriðið er hvort um sé að ræða sambærileg tilvik. Slíkt mat getur verið vandasamt en niðurstaða pess ræður pví hvort jafnræðisreglan á við. Á petta atriði reyndi m.a. í nýlegum dómi Hæstaréttar í máli nr. 121/2009 (Elín PH-82). Par kom fram að við mat á pví hvort reglur um úthlutun aflahlutdeildar í porski brytu gegn jafnræðisreglu 1. mgr. 65. gr. stjskr. yrði að bera saman báta sem hefðu verið í sambærilegri stöðu. Talið var að málefnaleg sjónarmið réttlættu að peir sem völdu að stunda veiðar í krókaaflamarkskerfi pegar pað stóð til boða á ákveðnum tíma væru ekki í sambærilegri stöðu og peir sem pá höfðu valið sóknardaga. Hinar umdeildu reglur voru pví ekki taldar fela í sér mismunun og pví ekki um að ræða brot gegn jafnræðisreglu 1. mgr. 65. gr. stjskr.

Sé niðurstaðan sú að um sambærileg tilvik sé að ræða parf að kanna hvort greinarmunur byggi á hlutlægum og málefnalegum sjónarmiðum. ${ }^{4}$ Við mat á pví hvort byggt er á slíkum sjónarmiðum kemur líkt og fyrir MDE til skoðunar hvort greinarmunur pjóni lögmætum markmiðum og samræmist kröfum um meðalhóf (Oddný Mjöll Arnardóttir, 2005, 462).

Dregin hefur verið sú ályktun af dómaframkvæmd Hæstaréttar að til sé stjórnskipuleg meðalhófsregla sem felur í sér að við takmörkun á mannréttindum megi löggjafinn ekki ganga of langt miðað við pað markmið sem að er stefnt og að sýna purfi fram á nauðsyn takmarkana (Björg Thorarensen, 2003, bls. 99; 2008, bls. 109-110). Með hliðsjón af dómaframkvæmd MDE um 14. gr. MSE hefur meðahófsmati í tenglsum við 65. gr. stjsrk. verið lýst svo að fram fari mat á pví hvort ekki sé „eðlilegt samræmi milli pess markmiðs sem mismunun stefnir að og peirra aðferða sem notaðar eru til að ná markmiðunum." (Björg Thorarensen, 2003, bls 69, sbr. einnig bls. 86). ${ }^{5}$

Athugun á dómum Hæstaréttar hefur jafnframt pótt leiða í ljós að áhersla á mat á meðalhófi við úrlausn stjórnskipulegra álitaefni fyrir Hæstarétti hefur farið vaxandi á undanförnum

\footnotetext{
${ }^{4}$ Bent hefur verið á að mat á pví hvort um sambærileg tilvik sé að ræða og pví hvort málefnaleg sjónarmið réttlæti mismunun fléttist oft saman (Björg Thorarensen, 2008, bls. 585). Rökstuðningur héraðsdóms og Hæstaréttar í ofangreindum dómi styður petta. Sjá einnig umfjöllun Oddnýjar Mjallar Arnardóttur um aðferðafræði MDE $(2005,449)$.

${ }^{5}$ Oddný Mjöll Arnardóttir hefur notað orðin „eðlilegt hlutfallslegt samhengi” $(2005,448)$ Í dómum MDE er petta mat almennt orðað svo á ensku „... Article 14 is ... violated when it is clearly established that there is no reasonable relationship between the means employed and the aim shought to be realised." (sjá t.d. Belgian Linguistics).
} 
árum og með mati á meðalhófi í tengslum við jafnræðisreglu stjórnarskrárinnar hafi dómstólar gengið lengra í að endurskoða ákvarðanir löggjafans en áður var viðurkennt. Er í pví sambandi einkum vísað til dóma Hæstaréttar í Veiðileyfamálinu (Hrd. í máli nr. 145/2008) og Vatneyrarmálinu (Björg Thorarensen, 2003, bls. 100-101).

Hæstiréttur vísar sjaldan berum orðum til meðalhófs við úrlausn stjórnskipulegra álitaefna og skýrir almennt ekki hvaða mælikvarðar liggja að baki mati á meðalhófi (Sjá nánar Björg Thorarensen, 2003, bls. 99-103). Finna má dæmi um hið gagnstæða í nokkrum nýlegum dómum sem varða 72. og/eða 75. gr. stjskr. Par kemur fram að kanna verði pau úrræði sem valin hafa verið „miðað við pá hagsmuni, sem í húfi voru, og hvort beitt hafi verið vægasta úrræðinu, sem að gagni kæmi.“ (Hrd. í máli nr. 220/2005). Einnig hefur komið fram að kanna verði hvort ekki sé með öðrum úrræðum unnt með „ásættanlegu” móti að ná peim tilgangi sem að er stefnt (Hrd. í máli nr. 425/2008). Samkvæmt pessu virðist hin stjórnskipulega meðalhófsregla geta falið í sér tvípætt mat. Í fyrsta lagi hvort velja hafi mátt önnur og vægari úrræði til að ná peim markmiðum sem að er stefnt. Tilvitnað orðalag gefur til kynna að fram geti farið ákveðinn samanburður á pví hversu áhrifarík möguleg úrræði eru (sbr. orðin „sem að gagni kæmi” og „,ásættanlegur”). Löggjafanum sé ekki frjálst að velja alltaf áhrifaríkasta úrræðið, standi önnur ,ásættanleg” úrræði til boða. Mælikvarðinn er augljóslega afar matskenndur og getur falið í sér endurskoðun á pólitískri stefnumörkun við val á leiðum. Í öðru lagi virðist svo geta komið til skoðunar hversu ríkir hagsmunir eru í húfi. Slíkt mat pýðir að vega parf einstaklingshagsmuni sem njóta stjórnskipulegrar verndar gagnvart öðrum einstaklingshagsmunum sem kunna að njóta stjórnskipulegrar verndar og/eða almannahagsmunum.

Peir mælikvarðar sem lagðir verða til grundvallar við mat á meðalhófi eru pví matskenndir og svigrúm löggjafans háð pví hve strangt matið er. Færð hafa verið rök fyrir pví að Hæstiréttur hafi markað svigrúm löggjafans á grundvelli sambærilegra sjónarmiða og MDE hefur markað svigrúm ríkja til mats. Viðurkennd sjónarmið um valdmörk löggjafans og dómstóla í lýðræðissamfélagi feli pað í sér að dómstólar fari varlega við að endurskoða pólitískt og efnahagslegt mat löggjafans. Hins vegar kunni ákveðin megin viðhorf í landsrétti og hugsanlega einnig pjóðarétti að leiða til pess að dómstólar gangi lengra við endurskoðun á mati löggjafans. Vísað er til röksemda Hæstaréttar í Vatneyrarmálinu sem dæmi pessa (Oddný Mjöll Arnardóttir, 2005, 462-263. Um sambærileg viðhorf sjá einnig Björg Thorarensen, 2003, 88-89). Heildstæð athugun á dómum Hæstaréttar sem varða jafnræðisreglu 65. gr. stjskr. hefur gefið til kynna að meðalhófsmatið geti verið missjafnlega strangt (Oddný Mjöll Arnardóttir, 2005, bls. 463). Matið geti m.a. ráðist af atvikum máls, s.s. á hvaða sviði greinarmunur er gerður og á hverju hann byggir. Pannig sé meðalhófsmat t.d. almennt ekki strangt ef greinarmunur snertir eignarréttindi. (Sjá nánar Oddný Mjöll Árnadóttir, 2005, bls. 463-467).

Í eftirfarandi umfjöllun um stjórnun fiskveiða og jafnræði verður í samræmi við pað leitast við að draga fram pau meginsjónarmið sem virðast hafa verið lögð til grundvallar í dómum 
Hæstaréttar sem snerta jafnræði og meðalhóf við stjórnun fiskveiða. Fyrst er pó rétt samhengisins vegna að gera stutta grein fyrir megin páttum stjórnkerfis fiskveiða og pá einkum peim markmiðum sem stefnt hefur verið að og helstu leiðum að peim.

\section{Markmið og leiðir við stjórnun fiskveiða}

\subsection{Almennt}

Stjórnkerfi fiskveiða í núverandi mynd á sér langa og flókna sögu par sem leitast hefur verið við að finna leiðir til að tryggja vernd fiskistofna og hagkvæma nýtingu peirra og útfæra pær með peim hætti að komið sé til móts hagsmuni peirra sem tengjast útgerð og fiskveiðum eða vilja hefja veiðar svo og heildarhagsmuni af pjóðhagslegum og samfélagslegum toga. Skiptar skoðanir hafa verið um hvaða hagsmunir eigi að njóta forgangs og hvaða leiðir séu best til pess fallnar að vernda pá. Ekki er ætlunin að rekja pessa sögu hér en um hana hefur verið ritað bæði í fræðiritum og skýrslum opinberra nefnda og annarra aðila sem komið hafa að endurskoðun kerfisins í gegnum tíðina (sjá t.d. Helgi Áss Grétarsson, 2008 og 2011 og skýrslur sjávarútvegsráđuneytis, 1993 og 2001 og sjávarútvegs- og landbúnaðarráðuneytis, 2010). Sagan sem par er rakin, aðdragandi og undirbúningur laga nr. 38/1990 og pau fjölmörgu lagafrumvörp sem lögð hafa verið fram á Alpingi um breytingar á stjórnkerfinu frá pví lög nr. 38/1990 voru sett, sýnir vel hve flókið viðfangsefnið er.

Stjórnun fiskveiða felur pví óhjákvæmilega í sér pólitískt mat um forgangsröðun og val á leiðum til að tryggja ólíka og oft á tíðum ósamrýmanlega einka- og almannahagsmuni. Sé litið til peirra sjónarmiða sem rakin eru í 2. kafla má ætla að dómstólar beiti ekki ströngu meðalhófsmati í tengslum við 65. gr. stjskr. og 75. gr. stjskr. Eins og nánar verður skýrt hér á eftir ber rökstuðningur Hæstaréttar, einkum í Veiðileyfamálinu, hins vegar annað með sér. Sama má segja um úrlausn Mannréttindanefndar Sameinuðu pjóðanna (MNSP) á pví hvort útfærsla aflamarkskerfisins á Íslandi samræmdist 26. gr. SBSR.

\subsection{Markmið fiskveiðistjórnunar}

Samkvæmt pjóðréttarskuldbindingum Íslands, sbr. einkum 61. og 62. gr. Hafréttarsáttmála Sameinuðu pjóðanna, er Íslandi skylt að gera ráðstafanir sem tryggja skynsamlega nýtingu fiskistofna í íslenskri efnahagslögsögu. Af markmiðsákvæðum löggjafar um stjórn fiskveiða má ráða að hún byggir á sambærilegum sjónarmiðum. Pannig segir í 1. gr. laga um umgengni við nytjastofna sjávar, nr. 57/1996, að lögunum sé ætlað að stuðla að sjálfbærri nýtingu nytjastofna sjávar sem tryggi hámarksafrakstur fyrir pjóðina. Pá segir í 1. gr. laga nr. 116/2006 um stjórn fiskveiða:

Nytjastofnar á Íslandsmiðum eru sameign íslensku pjóðarinnar. Markmið laga pessara er að stuðla að verndun og hagkvæmri nýtingu peirra og tryggja með pví trausta atvinnu og byggð í landinu. Úthlutun veiðiheimilda samkvæmt lögum pessum myndar ekki eignarrétt eða óafturkallanlegt forræði einstakra aðila yfir veiðiheimildum. 
Af athugasemdum við greinina í frumvarpi pví sem varð að lögum nr. 38/1990 má skýrlega ráða að með lögunum hafi átt að vernda pá ríku pjóðarhagsmuni sem tengjast nytjastofnum sjávar og tryggja að nýtingin pjóni heildarhagsmunum pjóðarinnrar. Par segir að nytjastofnar sjávar séu

langmikilvægasta auðlind íslensku pjóðarinnar og forsenda fyrir peirri próun efnahagslífs og íslensks samfélags er orðið hefur á pessari öld. (Pingskjal 1059. 19891990, athugasemdir við 1. gr.).

Pá segir að með 1. málsl. 1. gr. par sem nytjastofnum sjávar er lýst sem sameign pjóðarinnar sé minnt á mikilvægi pess að varðveita fullt forræði Íslendinga yfir henni og að í orðunum felist

... sú sjálfsagða stefnumörkun að markmiðið með stjórn fiskveiða er að nýta fiskstofnana til hagsbóta fyrir pjóðarheildina. Рað verður að vera ákvörðunarefni löggjafans á hverjum tíma, hvaða skipulag teljist best henta til að nýta pessa sameign pjóðarinnar með hagsmuni pjóðarheildarinnar að leiðarljósi. Með pví móti einu að tryggja hámarksafrakstur nytjastofna til langs tíma með lágamarkstilkostnaði, er unnt að skapa traustar forsendur fyrir atvinnu og byggð í landinu (Pingskjal 1059. 1989-1990, athugasemdir við 1. gr.).

Sú hugsun að inntak sameignar- eða pjóðareignarhugtaksins eigi að hafa sérstaka eignarréttarlega merkingu hefur birst víða (um samantekt á slíkum hugmyndum sjá t.d. Skúli Magnússon, 2011, 236 - 237) og m.a. komið fram í frumvarpi stjórnlagaráðs til nýrrar stjórnarskrár (Stjórnlagaráð, 2011, 34. gr.). Í lögfræðilegri rökræðu hefur hugtakið sameign pjóðarinnar í 1. málsl. greinarinnar pó almennt verið talið vísa til fullveldis íslenska ríkisins og fela í sér almenna markmiðsyfirlýsingu sem geti hugsanlega haft áhrif við lögskýringu (sbr. t.d. Sigurður Líndal, 1998, bls. 798; 2012, bls. 121; Helgi Áss Grétarsson, 2011, bls. 29-31). Í pví sambandi má benda á að pau sjónarmið hafa verið sett fram að auk almennrar markmiðsyfirlýsingar felist í ákvæðinu árétting um áðurnefnda reglu Grágásar og Jónsbókar um rétt manna til veiða innan peirra marka sem löggjafinn ákveður. Með lagasetningu sé löggjafinn að rækja pá skyldu sem hvíli á ríkisvaldinu að tryggja að nýting auðlindarinnar sé til hagsbóta fyrir pjóðarheildina (Porgeir Örlygsson, 1998, bls. 48-51). Í pví samhengi sem hér um ræðir er fyrst og fremst áhugavert að skoða hvort og að hvaða marki 1. málsl. 1. gr. getur haft áhrif við mat á meðalhófi í tengslum við jafnræðisræðisreglu 65. gr. stjskr. og atvinnufrelsisákvæði 75. gr. stjskr. Um pað verður nánar fjallað hér á eftir í umfjöllun um dóma Hæstaréttar.

\subsection{Leiðir við fiskveiðistjórnun}

Fiskveiðilöggjöfin samanstendur af mörgum lagabálkum par sem er að finna fjölda reglna sem takmarka frelsi til veiða. Pessar takmarkanir eru misjafnlega pungbærar og fela ekki allar í sér aðstöðumun manna á milli. Forsendur takmarkananna eru einnig ólíkar. Reglur um veiðarfæri og veiðisvæði sem m.a. eru settar með stoð í lögum um veiðar í 
fiskveiðilandhelgi Íslands, nr. 79/1997, byggja fyrst og fremst á líffræðilegum forsendum og fela alla jafna ekki í sér skerðingu á möguleikum manna til að hafa atvinnu af fiskveiðum. ${ }^{6}$ Pessar takmarkanir bitna almennt ekki sérstaklega pungt á einstökum aðilum eða hópum og fela almennt ekki í sér sérstök réttindi fyrir afmarkaðan hóp. Pað er pví ólíklegt að á jafnræðisreglu stjórnarskrárinnar reyni vegna peirra.

Ákvarðanir um leyfilegan heildarafla í einstökum tegundum eru einn mikilvægasti pátturinn í gildandi fiskveiðistjórnunarkerfi. Er ráðherra falið, að fengnum tillögum Hafrannsóknarstofnunar, að ákveða með reglugerð pann heildarafla sem veiða má á ákveðnu tímabili eða vertíð úr einstökum nytjastofnum sem pörf er á að takmarka veiðar úr, sbr. einkum 3. gr. laga nr. 116/2006. Aflatakmarkanir geta falið í sér skerðingu á atvinnufrelsi sem fellur undir 75. gr. stjskr. Eins og fram kom í 2. kafla má hins vegar skýrlega ráða af dómum Hæstaréttar að svigrúm löggjafans til slíkra skerðinga er rúmt vegna skyldu löggjafans að tryggja pá ríku pjóðarhagsmuni sem tengdir eru nytjastofnum sjávar. Ákvarðanir um heildarafla í einstökum tegundum eru að jafnaði almenns eðlis og pví ólíklegt að reyni á álitaefni um jafnræði vegna peirra.

Samhliða aflatakmörkunum hefur purft að grípa til ráðstafana til að tryggja að heildarafli fari ekki fram úr settum mörkum og að veiðar séu hagkvæmar. Ólíkar leiðir hafa verið reyndar, s.s. sóknarmark og takmarkanir á fjölda skipa (sóknarstýring) og svo aflamarkskerfi eins og pað sem nú er við líði (form nýtingarréttar). Pessi tæki, og pá einkum fjöldatakmarkanir og aflamarkskerfi, fela pað óhjákvæmilega í sér að velja parf hverjir fá að veiða og hve mikið. Раð verður með öðrum orðum að gera upp á milli manna. Eins og fram er komið, parf pað ekki að fela í sér brot á jafnræði pótt gerður sé greinarmunur á milli manna og pað jafnvel pótt peir séu í sambærilegri stöðu ef greinarmunurinn er réttlætanlegur á grundvelli hlutlægra og málefnalegra sjónarmiða.

Við setningu laga nr. 38/1990 var eftir nokkurn mótunartíma (árin 1984-1990) ákveðið að byggja að meginstefnu til á aflamarkskerfi. Á mótunartímanum höfðu útgerðir hins vegar átt ákveðið val um hvort skip væru gerð út innan aflamarkskerfis eða sóknarmarkskerfis. Sóknarmarkskerfið pótti ekki hafa gefist vel til að halda veiddum afla innan settra marka auk pess sem pað hafði skapað hvata til fjárfestinga í aukinni afkastagetu (Pingskjal 609, 19891990, 21. mgr. almennra athugasemda). Um tilgang aflamarkskerfisins sagði m.a. í frumvarpinu:

Frumvarpinu er ætlað að skapa sjávarútveginum almenna umgjörð og leikreglur. Innan pess ramma er peim er við sjávarútveg vinna hins vegar falið að taka ákvarðanir á pann hátt sem peir telja hagkvæmastan. Með pví að nýta pekkingu og

\footnotetext{
${ }^{6}$ Hæstiréttur hefur t.d. hafnað pví að bann við veiðum á afmörkuðum svæðum setji skorður við atvinnufrelsi manna í skilningi 75. gr. stjskr. (Hrd. í máli nr. 157/1999). Pá hafnaði Hæstiréttur pví í nýlegum dómi að bann við dragnótaveiðum á ákveðnu svæði færi gegn 75. gr. stjskr. (Hrd. Í máli nr. 443/2011).
} 
dugnað peirra er gerst til pekkja má ætla að hámarksafrakstri af fiskveiðiauðlindinni verði náð fyrir pjóðfélagið í heild. (Pingskjal 609, 1989-1990, 15. mgr. almennra athugasemda).

Einnig var ákveðið að viðhalda peim takmörkunum sem gilt höfðu á mótunartímanum á fjölgun fiskiskipa. Petta var talið nauðsynlegt til að aðlaga afkastagetu fiskiskipaflotans að afrakstursgetu fiskstofnanna. Gert var ráð fyrir óhætt yrði að afnema pessar fjöldatakmarkanir pegar frá liði og aflamarkskerfið hefði sýnt virkni sína í að ná pessum markmiðum. (Pingskjal 609, 1989-1990, athugasemdir 5. gr. og 20. mgr. almennra athugasemda). Pá pótti mikilvægt að tímabinda ekki löggjöfina, eins og gert hafði verið undanfarin ár, par sem að með pví var tryggður ákveðinn fyrirsjáanleiki í rekstri sem var talin „forsenda pess að pað hagræði náist sem fiskveiðistjórnin býður upp á, t.d. varðandi flotastærð.“ (Pingskjal 609, 1989-1990, 17. mgr. almennra athugasemda).

Með lögum nr. 38/1990 var pví að meginstefnu til komið á tvípættu kerfi takmarkana á heimildum stærri skipa (pá m.v. skip stærri en 10 brúttólestir) til veiða. Annars vegar var í 5. gr. laganna mælt fyrir um að eingöngu pau skip sem höfðu leyfi til veiða í íslenskri fiskveiðislögsögu við gildistöku laganna gætu fengið almennt leyfi til veiða í íslenskri fiskveiðilögsögu. Tengdist viðmiðið peim takmörkunum sem komið var á árið 1984, sbr. 3. gr. reglugerðar nr. 114/1984 um stjórn botnfiskveiða 1984. 5. gr. laga nr. 38/1990 náði til allra veiða, óháð pví hvort veitt var í tegundum sem sættu ákvörðun um heildarafla eða ekki. Hins vegar var í 7. gr. laganna mælt fyrir um að hverju skipi skyldi úthlutað tiltekinni hlutdeild af leyfðum heildarafla (aflahlutdeild) í einstökum tegundum. Aflahlutdeildin skyldi haldast óbreytt milli ára og var heimilt að framselja hana, sbr. 4. mgr. 11. gr. laganna. Heimildir skips til veiða á hverju fiskveiðiári, veiðitímabili eða vertíð skyldi svo ráðast af leyfðum heildarafla í viðkomandi tegund og hlutdeild skipsins í peim heildarafla (aflamark). Úthlutun aflahlutdeildar í tegundum sem sættu heildaraflatakmörkunum við gildistöku laganna fór fram skv. bráðabirgðaákvæði I við lögin. Í grundvallaratriðum pýddi petta að aflahlutdeildir skipa réðust af veiðireynslu skipa á tímabilinu 1. nóvember 1980 til 31. október 1983, að teknu tilliti til endurákvörðunar aflamarks skipa sem veitt höfðu í sóknarmarkskerfi fram til ársins 1990. Um úthlutun í tegundum sem sættu heildaraflatakmörkunum eftir gildistöku laganna fór skv. 3. gr. laganna. Par kom fram að ráðherra skyldi úthluta aflahlutdeild í tegundum sem samfelld veiðireynsla var á og að hún skyldi miðast við aflareynslu síðustu priggja veiðitímabila.

Fjölmargar breytingar hafi verið gerðar á fiskveiðistjórnunarkerfinu sem ekki eru efni til að rekja hér. Helst er að nefna að eftir dóm Hæstaréttar í Veiðileyfamálinu var áðurnefnt skilyrði fyrir almennu veiðileyfi fellt niður, sbr. 1. gr. laga nr. 1/1999. Eftir breytinguna hafa öll skip í eigu íslenskra aðila sem uppfylla almenn skilyrði um haffæri og skráningu á skipaskrá getað fengið almennt veiðileyfi, sbr. nú 4. gr. laga nr. 116/2006. Pá má nefna að í gegnum tíðina hefur heildaraflahlutdeild fiskiskipa sætt ýmsum skerðingum með pví að hluti heildaraflans kemur ekki til úthlutunar heldur er honum ráðstafað í sértækum tilgangi, 
s.s. til línuívilnunar, byggðapróunar og strandveiða, sbr. nánar upptalningu 5. mgr. 10. gr. laga nr. 116/2006. Grunnpættir kerfisins sem snúa að úthlutun aflahlutdeilda, ráðstöfun og varanleika standa hins vegar enn í megin atriðum, sbr. nú 8. og 9. gr. laga nr. 116/2006.

\section{Svigrúm löggjafans við val á leiðum við fiskveiðistjórnun}

Á stjórnskipulegt gildi fiskveiðistjórnunarkerfisins út frá sjónarmiðum um jafnræði og meðalhóf reyndi fyrst í Veiðileyfamálinu par sem lagt var fyrir Hæstarétt að meta hvort skilyrði 5. gr. laga nr. 38/1990 fyrir veitingu almenns veiðileyfis samræmdist 75. gr. og 1. mgr. 65. gr. stjskr. ${ }^{7}$ Niðurstaða Hæstaréttar var að svo væri ekki. Í kjölfarið kom svo til úrlausnar Hæstaréttar í Vatneyrarmálinu hvort úthlutun ótímabundinna og framseljanlegra aflahlutdeilda, sbr. 7. gr. págildandi laga um stjórn fiskveiða, samræmdist pessum stjórnarskrárákvæðum. Eins og vel er pekkt komst Hæstiréttur par að gagnstæðri niðurstöðu. Hæstaréttur beitti sömu greiningaraðferð í báðum málunum við mat á pví hvort reglurnar fælu í sér ólögmæta mismunun. Í úrlausnunum er byggt á pví að reglurnar hafi takmarkað frelsi manna til að velja sér starf við fiskveiðar og að með peim hafi verið gert upp á milli peirra sem áttu skip og gerðu út á ákveðnu tímabili og allra annarra sem vildu hefja veiðar. Virðist hafa verið litið svo á að pessir aðilar hafi verið í sambærilegri stöðu og pví purft að kanna hvort greinarmunurinn væri réttlætanlegur (sjá einnig Björg Thorarensen, 2008, bls. 589). Í báðum málunum kom pví til skoðunar hvort greinarmunurinn væri byggður á málefnalegum sjónarmiðum og réðst niðurstaðan af mati á pví hvort munurinn samræmdist meðalhófi.

\subsection{Aðferðir Hæstaréttar við mat á meðalhófi}

Eins og áður segir má almennt séð ætla í ljósi peirra pólitísku og efnahagslegu sjónarmiða sem liggja að baki fiskveiðistjórnunarkerfinu að ekki verði beitt ströngu meðalhófsmati í tengslum við takmarkanir á frelsi til veiða sem fela í sér greinarmun á grundvelli eignarréttarlegrar stöðu. Dómar Hæstaréttar í Veiðileyfamálinu og Vatneyrarmálinu virðast pó bera annað með sér. (Sjá einnig Björg Thorarensen, 2003, bls. 82-89. Um Vatneyrardóminn sjá Oddný Mjöll Arnardóttir, 2000, bls. 276-281).

Í Veiðileyfamálinu lagði Hæstiréttur mat á pað hvort nauðsynlegt hefði verið að binda almennt leyfi til veiða við pá sem höfðu yfir að ráða skipi sem haldið var til veiða á ákveðnu tímabili, sbr. 5. gr. laga nr. 38/1990. Um pað sagði í dóminum:

Pótt tímabundnar aðgerðir af pessu tagi til varnar hruni fiskistofna kunni að hafa verið réttlætanlegar, en um pað er ekki dæmt í málinu, verður ekki séð, að rökbundin nauðsyn hnígi til pess að lögbinda um ókomna tíð pá mismunun, sem leiðir af reglu 5. gr. laga nr. 38/1990 um úthlutun veiðiheimilda. Stefndi hefur ekki sýnt fram á, að aðrar leiðir séu ekki færar til að ná pví lögmæta markmiði að vernda fiskistofna við Ísland.

\footnotetext{
${ }^{7}$ Sbr. afmörkun Hæstaréttar á dóminum í V. kafla Vatneyrardómsins.
} 
Athugun Hæstaréttar á nauðsyn greinarmunarins fól í sér strangt meðalhófsmat sem birtist m.a. í pví að ríkinu var gert að sýna fram á að aðrar leiðir hefðu ekki verið færar til að ná tilætluðum markmiðum. Hæstiréttur framkvæmdi í pví sambandi ákveðið hagsmunamat par sem hann leggur punga vigt á frelsi til veiða sem hann styður með tilvísun til atvinnufrelsisákvæðis 75. gr. stjskr. og sameignarhugtaks 1. málsl. 1. gr. laga nr. 38/1990. Dómurinn skilgreindi hins vegar nauðsyn greinarmunarins aðeins út frá pörfinni á að „varna hruni fiskstofna". Verður pað að teljast mjög pröngt sjónarhorn á bæði almenn markmið 1. gr. laganna um vernd og hagkvæma nýtingu fiskistofna og pau sérstöku markmið 5. gr. að ná jafnvægi milli afkastagetu skipaflotans og afrakstursgetu fiskistofna.

Pví má vissulega halda fram að með pví að viðhalda takmörkunum á stærð fiskipskipaflotans samhliða aflamarkskerfinu hafi löggjafinn sett bæði belti (fjöldatakmarkanir 5. gr.) og axlabönd (aflamarkskerfið) til að takmarka vaxandi afkastagetu skipaflotans. Fjöldatakmarkanirnar hafi pví ekki verið nauðsynlegar. (Skúli Magnússon, 2000, bls. 643). Í dómi Hæstiréttur er pó ekki skýr um petta atriði par sem dómurinn vísar til pess að ekki hafi verið nauðsynlegt að viðhalda fjöldatakmörkunum um „ókomna tíð." Petta má skilja svo að rétt hefði verið að binda gildistíma peirra við ákveðinn tíma og endurmeta pörfina. Eins og áđur hefur verið vikið að má hins vegar ráða af lögskýringargögnum að löggjafanum var ætlað að meta pörfina á að viðhalda skilyrðinu samhliða aflamarkskerfinu í ljósi próunar á afkastagetu fiskiskipaflotans. Рað má pví segja að pörfin hafi í raun sætt stöðugu mati löggjafans. Með dómi Hæstaréttar í Veiðileyfamálinu var mat löggjafans hins vegar endurskoðað.

Í Vatneyrarmálinu kom til skoðunar eftir hvaða leiðum löggjafanum væri heimilt að útdeila heimildum til veiða í tegundum sem heildarafli var takmarkaður á. Hæstiréttur framkvæmdi ítarlegt mat á meðalhófi en gekk ekki eins langt í að endurskoða mat löggjafans við val á leiðum. Hæstiréttur lagði fyrst mat á hvort upphafleg úthlutun aflahlutdeilda hefði samræmst kröfum stjórnarskrárinnar um jafnræði.

Um petta atriði sagði m.a. í dóminum:

Pegar litið er til peirra hagsmuna af atvinnu og fjárfestingum, sem bundnar hafa verið sjávarútvegi, og reynslu og pekkingar pví samfara, verður að telja að pað hafi verið samrýmanlegt jafnræðisrökum að deila takmörkuðum heildarafla milli skipa, sem pá stunduðu veiðar, pótt löggjafinn hafi átt úr fleiri kostum að velja.

Með pessum orðum lagði Hæstiréttur mat á og féllst á pær forsendur sem löggjafinn lagði til grundvallar við val á peim hópi sem skyldi eiga rétt á úthlutun veiðiheimilda við gildistöku laganna. Tilvísun Hæstaréttar til pess að aðrir kostir hafi einnig verið í stöðunni felur í sér 
áréttingu um að dómstólar endurskoði ekki val löggjafans á leiðum við úthlutun veiðiheimilda ef valið byggir á málefnalegum sjónarmiðum. ${ }^{8}$

Hæstiréttur tók pví næst til skoðunar hvort nánari útfærsla kerfisins samræmdist meðalhófssjónarmiðum. Í pví sambandi var lagt mat á hvort ómálefnalegt væri að úthluta aflahlutdeildum með ótímabundnum hætti. Hæstiréttur taldi svo ekki vera. Í röksemdarfærslu Hæstaréttar var lagt mat á meðalhóf út frá pví hversu rík takmörkun á aðgangi til fiskveiða fælist í fyrirkomulaginu og hvernig hún samræmdist peim markmiðum sem að var stefnt. Um aðgang að manna að fiskveiðum benti Hæstiréttur á að peir sem ekki áttu rétt á úthlutun aflahlutdeilda, eða vildu auka við heimildir sínar, gætu veitt úr stofnum sem ekki sættu heildaraflatakmörkunum. Pá ættu pessir aðilar einnig kost á pví að kaupa aflahlutdeild eða aflamark. Skipti heimildin til framsals pví máli við mat á pví hversu rík takmörkun fælist í ótímabundinni úthlutun aflahlutdeildar.

Hæstiréttur fjallaði pví næst ítarlega um pau rök sem lágu að baki takmörkunum og lagði mat á hvort pær samræmdust markmiðum laganna. Í pví sambandi sagði dómurinn m.a.:

Sú tilhögun að aflaheimildir séu varanlegar og framseljanlegar styðst að auki við pau rök að með pessu sé mönnum gert kleift að gera áætlanir um starfsemi sína til lengri tíma og auka eða minnka aflaheimildir sínar í einstökum tegundum eftir pví, sem hentar hverju sinni. Eru lögin að pessu leyti reist á pví mati, að sú hagkvæmni, sem leiði af varanleika aflahlutdeildar og heimildum til framsals hennar og aflamarks, leiði til arðbærrar nýtingar fiskstofna fyrir pjóðarbúið í samræmi við markmið 1. gr. laganna. Til pess verður og að líta að samkvæmt 3. málslið 1. gr. laganna myndar úthlutun veiðiheimilda ekki eignarrétt eða óafturkallanlegt forræði einstakra manna yfir peim, eins og áður segir. Aflaheimildir eru pannig aðeins varanlegar í peim skilningi að pær verða hvorki felldar niður né peim breytt nema með lögum.

Pessi hluti úrlausnarinnar sýnir að Hæstiréttur tekur ekki aðeins gild rök er snúa að verndun fiskistofna heldur einnig efnahagslegum markmiðum. Nálgun Hæstaréttar er að pessu leyti önnur en í Veiðileyfamálinu. Rökstuðningurinn gefur einnig til kynna að dómstóllinn kanni hvort fyrir liggi að fyrirkomulag ótímabundinna og framseljanlegra aflahlutdeilda samræmist hagsmunum pjóðarheildarinnar. Dómstóllinn virðist fallast á gildi raka löggjafans fyrir pví að svo sé en leggur ekki skýrlega mat á pau. ${ }^{9}$ Heildarmat á úrlausn dómsins um lögmæti aflatakmarkana skv. 75. gr. stjskr. og aflamarkskerfisins skv. 65. gr. stjskr. sýnir að peir ríku pjóðarhagsmunir sem eru tengdir fiskveiðum vega pungt inn í mat

\footnotetext{
${ }^{8}$ Hæstiréttur hefur með sömu rökum fallist á lögmæti úthlutunar aflahlutdeilda í norsk-íslenska síldarstofninum (Hrd. í máli nr. 221/2004 (Hoffellsmálið)).

${ }^{9}$ Oddný Mjöll Arnardóttir færir rök fyrir pví að Hæstiréttur hafi fallist á mat löggjafans og lagt sjálfstætt mat á að inntak peirra réttinda sem fylgja aflaheimildum samræmist 1. gr. laga nr. 38/1990, 2000, bls. 280.
} 
dómsins á svigrúmi löggjafans. Mikilvægi hagsmunanna gefa löggafanum rúma heimild til takmarkana á atvinnufrelsinu en prengja svigrúmið til pess að gera upp á milli manna að pví leyti að löggjafinn verður að færa skýr rök fyrir pví að greinarmunurinn pjóni hagsmunum pjóðarheildarinnar.

Samanburður á málunum sýnir að meðalhófsmatið var misjafnlega strangt að pví leyti að Hæstiréttur gekk ekki eins langt í Vatneyrarmálinu í að endurmeta nauðsyn takmarkananna. Áhugavert er að skoða nánar hvaða ástæður liggja par að baki.

\section{2. Áhrifapættir við val á leiðum við mat á meðalhófi}

\subsubsection{Hversu rík er mismunin?}

Augljósasta skýringin á ólíku svigrúmi löggjafans í málunum tveimur er að hin umdeildu skilyrði 5. gr. laga nr. 38/1990 hafi falið í sér ríkari takmörkun á frelsi til veiða en regla 7. gr. um úthlutun aflahlutdeilda (sjá m.a. Karl Axelsson, 2000, bls. 271; Oddný Mjöll Arnardóttir, 2005, 463). Раð leiðir af kjarna meðalhófsmatsins að pví ríkari sem skerðing á verndarhagsmunum er pví sterkari rök parf að færa fram fyrir pví að skerðingarinnar sé pörf. Í Vatneyrarmálinu skýrir Hæstiréttur raunar sjálfur ólíka niðurstöðu meðalhófsmatsins á pessum forsendum. Par segir:

Pessum skorðum á aðgangi manna að nytjastofnum (p.e. peim sem leiddu af 7. gr., innsk. höf.) verður ekki jafnað til peirrar ómálefnalegu mismununar, sem hlaust af reglum 5. gr. laga nr. 38/1990, sem áskildu veiðileyfi með hliðsjón af eignarhaldi á skipum á tilteknum tíma án tillits til pess, hvort nauðsyn bar til aflatakmarkana, og lokuðu pannig í meginatriðum aðgangi manna að atvinnugreininni.

\subsubsection{Mikilvægi hagsmuna}

Eins og fram hefur komið hefur Hæstiréttur lagt áherslu á pá ríku almannahagsmuni sem tengdir eru vernd og hagkvæmri nýtingu fiskistofna. Kann pað að skýra ítarlegt mat á meðalhófi í báðum málunum (sjá einnig Björg Thorarensen, 2003, bls. 89). •að skýrir hins vegar ekki muninn á pví hversu langt dómstóllinn gengur í að endurskoða val löggjafans á leiðum. Almannahagsmunirnir sem tengjast fiskveiðistjórnun eru margpættir og ná m.a. til efnahagslegra hagsmuna pjóðarinnar af fiskveiðum. Eins og áður segir virðist horft fram hjá efnahagslegum markmiðum 5. gr. laga nr. 38/1990 í Veiðileyfadóminum. Í

Vatneyrardóminum eru slíkir hagsmunir hins vegar teknir inn í mat á pví hvort fyrirkomulag 7. gr. samræmist meðalhófssjónarmiðum. Út frá almennum sjónarmiðum um mörk endurskoðunarvalds dómstóla getur pessi ólíka afmörkun á markmiðum ákvæðanna hafa haft áhrif á pað hversu langt dómstóllinn taldi segi geta gengið við mat á nauðsyn ráðstafananna. 


\subsubsection{Inntak sameignarhugtaksins}

Nátengt hagsmunamatinu er afmörkun Hæstaréttar á sameignarhugtaki 1. málsl. 1. gr. laga nr. 38/1990. Ólíkur skilningur virðist lagður í hugtakið í málunum. Í Veiðileyfadóminum segir að með 5. gr. laga nr. 38/1990 hafi verið lögð

fyrirfarandi tálmun við pví, að drjúgur hluti landsmanna geti, að öðrum skilyrðum uppfylltum, notið sama atvinnuréttar í sjávarútvegi eða sambærilegrar hlutdeildar í peirri sameign, sem nytjastofnar á Íslandsmiðum eru (áherslubr. höf.), og peir tiltölulega fáu einstaklingar eða lögaðilar, sem höfðu yfir að ráða skipum við veiðar í upphafi umræddra takmarkana á fiskveiðum.

Í pessum orðum felst að pau réttindi sem skerðingin snerti séu ekki aðeins tengd frelsi til veiða heldur einnig möguleikum landsmanna á að njóta „,sambærilegrar hlutdeildar í sameigninni“. Ekki er fyllilega skýrt til hvers Hæstiréttur vísar með pessum orðum. Pau má túlka svo að í sameignarhugtakinu felist sérstakur eignarréttur sem njóti stjórnskipulegrar verndar (um sambærileg skýringu sjá t.d. Karl Axelsson, 2000, bls. 271). Sameigendurnir (pjóðin) eigi að íslenskri stjórnskipan óskiptan rétt til hagnýtingar auðlindarinnar og arðs af henni.

Dómur Hæstaréttar í Vatneyrarmálinu gefur hins vegar ekki til kynna að rétt sé að skýra sameignarhugtakið með pessum hætti. Heildarmat á rökstuðningi Hæstaréttar í málinu bendir fremur til pess að sameignarhugtakið vísi til ákveðinna grunnsjónarmiða um að löggjafanum sé skylt að stjórna fiskveiðum til hagsbóta fyrir pjóðarheildina. Pessi skýring er í samræmi við pau sjónarmið sem fram koma í lögskýringargögnum (sjá kafla 3.2) og skoðanir fræðimanna (sjá einkum Porgeir Örlygsson, 1998, bls. 48-51).

Báðir skýringarkostirnir takmarka svigrúm löggjafans til að gera upp á milli manna við stjórnun fiskveiða en ætla má að fyrri skýringarkosturinn setji löggjafanum skýrari mörk við val á leiðum. ${ }^{10}$ Síðari skýringarkosturinn leggur pað fyrst og fremst á löggjafann að færi skýr rök fyrir pví að sú leið sem valin er samræmist hagsmunum pjóðarheildarinnar.

Í pessu sambandi er rétt að benda á að dómar Hæstaréttar í Veiðileyfamálinu og Vatneyrarmálinu hafa verið túlkaðir svo að „mismunun á grundvelli eignarhalds eða fjárhagslegra hagsmuna hafi ekki kallað á sérlega strangt meðalhófsmat, en að peir mikilvægu hagsmunir tengdir atvinnufrelsinu sem tekist var á um hafi frekar ráðið niðurstöðu" (Oddný Mjöll Arnardóttir, 2005, bls. 463-464). Með pessu er ekki gerður greinarmunur á efnislegri afmörkun sameignarhugtaksins í málunum. Pess í stað virðist á pví byggt að í báðum málunum hafi legið að baki hugmyndir um að sameignarhugtakið endurspegli ákveðin meginviðhorf og grunnsjónarmið um stöðu fiskveiðiauðlindarinnar.

\footnotetext{
10 Í pessu sambandi má nefna að í séráliti Guðrúnar Erlendsdóttur og Haraldar Henrysonar sem bæði áttu sæti í dómi Hæstaréttar í Veiðileyfamálinu eru færð rök fyrir pví að 7. gr. laga nr. 38/1990 brjóti gegn kröfum stjórnarskrárinnar um jafnæði og í pví sambandi m.a. byggt á sameignarhugtaki 1. málsl. 1. gr. laga nr. 38/1990.
} 


\section{3. Álit MNSP í Fagramúlamálinu}

Áhugavert er að skoða álit MNSP Fagramúlamálinu í samhengi við umfjöllun um dóma Hæstaréttar en í málinu reyndi á sömu efnisatriði og í Vatneyrarmálinu. Í pví máli komst meiri hluti nefndarinnar að peirri niðurstöðu að úthlutun ótímabundinna og framseljanlegra aflahlutdeilda bryti gegn 26. gr. SBSR. Nefndin byggði álitið á pví að í 1. gr. laga nr. 38/1990 væri nytjastofnum í íslenskri lögsögu lýst sem sameiginlegri eign pjóðarinnar. Á sama tíma hefði með lögunum verið komið á kerfi varanlegra og framseljanlegra aflahlutdeila sem hafi skapað peim sem fengu úthlutað aflahlutdeild einkaeignarrétt sem ekki samrýmdist 1. gr. laganna. Taldi nefndin að ákveðinn hópur útgerðaraðila hefði pví fengið í hendurnar varanleg eignarréttindi á kostnað annarra útgerðaraðila sem pyrftu að leigja eða kaupa pessi réttindi. Petta fyrirkomulag var ekki talið samræmast kröfum um sanngirni. ${ }^{11}$ Nefndin virðist pví leggja sjálfstæðan skilning á inntak laga nr. 38/1990 og lýsa ósamræmi milli markmiða laganna og peirra leiða sem löggjafinn valdi.

Ekki verður skýrt ráðið af áliti MNSP hvaða lagabreytingar purfi að gera svo kerfið samrýmist 26. gr. samningsins. Pað má skýra álitið svo að binda purfi úthlutun aflahlutdeilda við ákveðinn tíma og tryggja að stjórnvöld geti ráðstafað peim að nýju á grundvelli sanngjarnra og hlutlægra sjónarmiða. Petta verður pó ekki svo óyggjandi sé ráðið af álitinu. Í ljósi pess að búið er að loka málinu með peim rökum að stjórnvöld hafi brugðist við pví „,með ásættanlegum hætti að hluta til” (utanríkisráðuneytið, 2012) má reyndar draga pað í efa að svo viðamikilla lagabreytinga sé pörf.

\section{4. Ályktanir um meðalhófsmat og svigrúm löggjafans.}

Af umfjölluninni hér að framan má ráða að vandasamt er að draga almennar ályktanir um svigrúm löggjafans. Svigrúmið markast af atvikum máls, s.s. pví hversu rík takmörkun er, en einnig af pví hvaða inntak og vægi markmiðum laga er gefið. Í pví sambandi virðist nálgun Hæstaréttar við skýringu á inntaki sameignarhugtaks 1. gr. laga nr. 116/2006 hafa skipt máli. Pó má draga pá almennu ályktun að Hæstiréttur leggi pað til grundvallar við meðalhófsmatið að löggjafanum beri að stjórna fiskveiðum með hagsmuni pjóðarheildarinnar að leiðarljósi og að löggjafinn verði pví ávallt að færa skýr rök fyrir pví að ráðstafanir sem takmarka aðgang manna að veiðum og gera upp á milli peirra samræmist hagsmunum pjóðarheildarinnar. Hæstiréttur virðist meta hvort slík rök liggi fyrir og kann að telja slíkar ráðstafanir ónauðsynlegar ef samræmið er óljóst.

Röksemdarfærsla Hæstaréttar í Vatneyrarmálinu gefur auk pess sértækari leiðbeiningu um hvernig standa megi að skiptingu veiðiheimilda og nánari útfærslu kerfisins. Hvað fyrra atriði snertir má draga pá ályktun að löggjafinn eigi mat um pað hvaða leið er farin við val á pví hverjir eigi rétt á að fá úthlutað veiðiheimildum enda sé valið byggt á málefnalegum

\footnotetext{
${ }^{11}$ Álitið hefur sætt gagnrýni, m.a. á peirri forsendu að nefndin hafi gengið mjög langt í að takmarka svigrúm ríkja vegna réttinda sem tengist frelsi til að velja atvinnu og liggja á sviði fiskveiðistjórnunar sem einkennist af flóknu samspili efnhagslegra- og félagslegra hagsmuna (Seibert-Fohr, A., 2010, 1116).
} 
forsendum. Pá má einnig draga pá ályktun að við slíkt val sé málefnalegt að taka tillit til hagsmuna af atvinnu og fjárfestingum sem hafa verið bundnar sjávarútvegi og reynslu og pekkingar pví samfara. Hvað síðara atriði snertir virðist koma til skoðunar að hve miklu leyti útfærsla kerfisins útiloki aðra frá veiðum. Í pví sambandi virðist m.a. geta skipt máli til hve langs tíma veiðiheimildum er úthlutað og að hvaða marki aðrir geta fengið veiðiheimildir, t.d. fyrir framsal.

\section{Samræmist frumvarp til laga um stjórn fiskveiða jafnræðisreglu íslenskrar stjórnskipunar?}

\subsection{Forsendur og markmið frumvarpsins}

Á síðastliðnu löggjafarpingi var lagt fram frumvarp til laga um stjórn fiskveiða sem m.a. átti að leysa af hólmi gildandi lög um stjórn fiskveiða nr. 116/2006. Frumvarpið hlaut ekki afgreiðslu og pegar petta er skrifað er unnið að nýju frumvarpi í atvinnuvega- og nýsköpunarráðuneytinu. Frumvarpið var, ásamt frumvarpi til laga um veiðigjald (Pingskjal 1053, 2011-2012) sem varð að lögum nr. 74/2012, afrakstur heildarendurskoðunar á löggjöf um stjórn fiskveiða sem staðið hefur yfir undanfarin ár. Í pví voru lagðar til ýmsar breytingar á gildandi stjórnkerfi. Peirra á meðal voru tillögur um grundvallarbreytingar á reglum um skiptingu leyfilegs heildarafla á milli útgerðaraðila. Í athugasemdum við frumvarpið voru færð bæði pólitísk og lögfræðileg rök fyrir breytingartillögunum. Par sagði m.a.:

Með frumvarpinu er leitast við að tryggja festu og öryggi í sjávarútvegi með tímabindingu aflahlutdeilda til langs tíma og fyrirsjáanleika um mögulegar breytingar á skipulagi sjávarútvegs. Um leið er komið til móts við önnur sjónarmið með tímabindingu réttinda, auknum möguleikum til nýliðunar, stofnun kvótapings og ráđstöfun aflamarks innan flokks 2. Pannig er með frumvarpinu leitast við að feta meðalveg til að ná peim samfélagslegu markmiðum sem stefnt er að við endurskoðun laga um stjórn fiskveiða (Pingskjal 1052, 2011-2012, athugasemdir, kafli 3.3).

Tilvitnuð orð sýna vel pá ólíku hagsmuni sem purfti að vega að mati frumvarpssmiða. Eins og fram kemur í textanum var ætlunin að feta ákveðinn meðalveg. Hin lögfræðilegu rök fyrir breytingartillögunum tengdust áliti MNSP í Fagramúlamálinu en eins og áður segir var álitið ekki skýrt um pað hvaða breytinga væri pörf. Áherslur í rökstuðningi nefndarinnar á varanleika úthlutunar aflahlutdeilda og framseljanleika peirra virðist pó hafa haft áhrif við smíði frumvarpsins.

Markmið frumvarpsins voru sundurliðuð í 1. mgr. 1. gr. pess. Í ákvæðinu gætti aukinnar áherslu frá pví sem nú er á hagsmuni komandi kynslóða. Pá var gerð skýrari grein fyrir hagrænum markmiðum fiskveiðistjórnunar. Pannig sagði að hámarka ætti pjóðhagslegan ávinning af sjávarauðlindinni og tryggja pjóðinni eðlilega auðlindarentu (d-liður) og að 
sjávarútvegurinn ætti að vera arðsamur og búa við hagstætt og stöðugt rekstrarumhverfi (eliður). Í 2. mgr. sagði svo

Nytjastofnar á Íslandsmiðum eru sameiginleg og ævarandi eign íslensku pjóðarinnar. Íslenska ríkið veitir tilskilin leyfi, fer með og ráðstafar hvers kyns heimildum til nýtingar. Slík veiting eða ráðstöfun myndar ekki eignarrétt eða óafturkallanlegt forræði einstakra aðila yfir peim.

Af athugasemdum við frumvarpið verður ekki ráðið að breyta hafi átt efnislegu inntaki greinarinnar (Pingskjal 1052, 2011-2012, athugasemdir kafli 1.1. og athugasemdir við 1. gr.) Pó kemur fram að orðalagið taki mið af tillögum stjórnlagaráðs (sem gekk út frá pví að sameignarhugtakið fæli í sér eignarrétt) og að við skýringu á inntaki pess skipti forsaga fiskveiðiréttinda við Ísland máli sem hafi frá fornu fari verið almenn. Pá er skírskotað til áður reifaðra sjónarmiða Porgeirs Örlygssonar um inntak ákvæðisins (sem virðist ekki ganga út frá pví að í sameignarhugtakinu felist eignarréttarleg merking). Erfitt er að draga ályktanir um inntak hugtaksins í frumvarpinu út frá pessum tilvísunum sem eru í raun misvísandi.

\subsection{Helstu breytingar á aflamarkskerfinu}

Í frumvarpinu var gert ráða fyrir að áfram yrði byggt á aflamarkskerfi við stjórnun fiskveiða en að á pví yrðu gerðar vissar grundvallarbreytingar. Í grófum dráttum voru breytingarnar tvípættar. Annars vegar var gert ráð fyrir að til yrðu tveir flokkar aflahlutdeilda. Í öðrum flokknum (flokkur 1) voru hlutdeildir sem pegar hefur verið úthlutað og gengið hafa kaupum og sölum. Í hinum flokknum (flokkur 2) voru hlutdeildir í ríkisforsjá sem ráðherra átti að hafa rúmar heimildir til að ráðstafa í sértækum tilgangi. Sá hluti heildaraflans sem féll í flokk 2 átti smám saman að aukast og hlutinn í flokki 1 átti að sama skapi að minnka. Hins vegar var gert ráð fyrir breyttu eðli peirra aflahlutdeilda sem pegar hefur verið úthlutað og féllu í flokk 1. Pannig var gert ráð fyrir að pær yrðu bundnar við nýtingarleyfi sem átti að vera tímabundið til a.m.k. 20 ára. Pá voru lagðar til hindranir við framsali peirra fyrstu 20 árin og svo algert bann að peim tíma liðnum.

\subsubsection{Flokkur 1}

Eðli og inntak nýtingarleyfa

Eins og áður segir var lagt til að tengja aflahlutdeildir í flokki 1 við nýtingarleyfi, sbr. 11. gr. frumvarpsins. Í athugasemdum við frumvarpið kom fram að petta fyrirkomulag leyfisveitinga yrði að mörgu leyti sambærilegt pví sem gildir um auðlindir á landi og í pví sambandi m.a. vísað til 1. og 2. mgr. 6. gr. laga nr. 57/1998, um rannsóknir og nýtingu auðlinda í jörðu og úthlutun leyfa til notkunar fjarskiptatíðna skv. IV. kafla laga nr. 81/2003 um fjarskipti. •á sagði að með pessu væru „réttindi handhafa aflahlutdeilda nánar afmörkuð og skilgreind og pannig dregið úr hættu á ýfingum og misskilningi. Um leið er forræði auðlindarinnar gert öllum ljóst." (Pingskjal 1052, 2011-2012, athugasemdir, kafli 2.5.). Í sjálfum texta 11. gr. frumvarpsins var sagt að nýtingarleyfi fæli í sér „ígildi samkomulags“ milli ríkisins og handhafa leyfis. Í orðunum virðist felast tilvísun til forsögu frumvarpsins 
par sem meirihluti starfshóps sem var falið að vinna tillögur að endurskoðun laga um stjórn fiskveiða hafði lagt til að farin yrði svokölluð samningaleið (Sjávarútvegs- og landbúnaðarráðuneytið, 2010, bls. 30-31). Hún gekk í aðalatriðum út á að ákveðnu hlutfalli heildaraflamarks yrði ráðstafað með samningum sem gerðir yrðu um nýtingu aflaheimilda til ákveðins tíma en með framlengingarrétti (Sjávarútvegs- og landbúnaðarráðuneytið, 2010, bls. 13 og 30-31). Ummæli í athugasemdum við frumvarpið (Pingskjal 1052, 2011-2012, kafli 2.5., lokamálsgrein) styðja að samningaleiðin hafi verið ákveðin fyrirmynd við útfærslu frumvarpsins.

\section{Gildistími nýtingarleyfa}

Nýtingarleyfi átti eins og áður segir að gefa út til 20 ára frá og með upphafi fiskveiðiárs 2012/2013. Réttindi peirra sem höfðu yfir að ráða aflahlutdeild breyttust pannig úr pví að vera ótímabundin réttindi í tímabundin réttindi. Upphafstíminn átti einnig við um nýtingarleyfi sem gefin yrðu út síðar á 20 ára tímabilinu, sbr. 4. mgr. 11. gr. Ný nýtingarleyfi áttu samkvæmt pví að hafa styttri gildistíma. Ekki kemur fram í frumvarpinu á hvaða forsendum var byggt við val á lengd tímans. Hins vegar er eins og áður segir vísað til pess í frumvarpinu að stuðst hafi verið við tillögur starfshópsins frá 2010 um svokallaða samningaleið (Sjávarútvegs- og landbúnaðarráðuneytið, 2010, bls. 30-31). Í skýrslunni er vísað til minnisblaðs sem unnið var fyrir nefndina. Í minnisblaðinu kom fram að ekki væri óeðlilegt að miða við að samningstíminn yrði 15-30 ár með framlengingarrétti. Með pví yrði „óvissu gagnvart stjórnvöldum eytt en jafnframt ... gætt að réttindum peirra sem nú fara með aflaheimildir."(Karl Axelsson og Lúðvík Bergvinsson, 2010, bls. 32-35).

\section{Framlenging nýtingarleyfa}

Í 3. mgr. 11. gr. frumvarpsins kom fram að ráðherra væri heimilt pegar 5 ár væru liðin frá útgáfu leyfis að tilkynna handhafa nýtingarleyfis um „grundvallarbreytingar eða brottfall leyfis" með 15 ára fyrirvara. Engar skýringar voru í frumvarpinu á pví hvað átt er við með grundvallarbreytingum. Ef ráðherra sendi ekki slíka tilkynningu áttu leyfin að framlengjast um eitt ár í senn án pess að sett væru efri mörk á gildistíma leyfis. Gert var ráð fyrir að áður en tilkynning yrði send pyrfti ráðherra að leita sampykkis Alpingis í formi pingsályktunartillögu. Ekki kom fram í frumvarpinu á hvaða sjónarmiðum ráðherra átti að byggja við mat á pví hvort slík tilkynning skyldi send eða ekki. Virðist hann aðeins hafa átt að færa fram rök fyrir mati sínu ef hann sendi tilkynningu. Pá er ekki skýrt af frumvarpinu hvort slík tilkynning ætti ávallt að taka til allra nýtingarleyfa. Pó virðist ljóst að með slíkri tilkynningu hafi ekki átt að taka afstöðu til einstakra nýtingarleyfa. Pannig segir í athugasemdum við frumvarpið að tilkynningu megi t.d. senda í formi opins bréfs eða reglugerðar (Pingskjal 1052, 2011-2012, kafli 2.5.). Pá myndi pað tæplega samræmast hlutverki Alpingis að taka afstöðu til einstakra stjórnvaldsákvarðana.

Af athugasemdum við frumvarpið má ráða að framlengingarheimildin hafi átt að tryggja útgerðum mikilsverðan „stöðugleika og fyrirsjáanleika“ (athugasemdir, kafli 2.5., 
lokamálsgrein). Pá hafi hún átt að verða til pess að báðir aðilar leituðust við „að viðhalda og varðveita auðlindina sem nýtingarréttindin byggjast á eins og best verður kosið“. Með pessu virðist vísað til svipaðra sjónarmiða og skírskotað var til um í áđurnefndu minnisblaði Karls Axelssonar og Lúðvíks Bergvinssonar í tengslum við samningaleið. Í pví sambandi er mikilvægt að hafa í huga að par var gert ráð fyrir að um væri að ræða gagnkvæma samninga milli einstakra útgerðaraðila og ríkisins par sem báðir aðilar tækju á sig skyldur um að umgangast auðlindina með ábyrgum hætti. Miðað var við að samningarnir yrðu til ákveðins tíma en með rétti til framlengingar ef öll skilyrði samnings væru uppfyllt. Pannig væri tryggður fyrirsjáanleiki í rekstri og stuðlað að ábyrgri umgengni við auðlinda (Karl Axelsson og Lúðvík Bergvinsson, 2010, bls. 35). Samningsgerðin og rétturinn til framlengingar á samningi byggði pví á peirri forsendu að um væri að ræða tvíhliða samningssamband og að um framlengingu á honum færi eftir mati á hverjum og einum útgerðaraðila. Eins og áður segir virðist pessu hafa átt að vera öðruvísi farið með nýtingarleyfi. Sömu rök fyrir framlengingu eiga pví augljóslega ekki við par sem einstakir útgerðaraðilar virðast ekki hafa getað haft áhrif á pað með ábyrgri hegðun hvort af framlengingu yrði og enginn fyrirsjáanleiki tryggður um á hvaða forsendum ákvörðun um framlengingu yrði byggð.

\section{Framseljanleiki}

Í 4. mgr. 12. gr. frumvarpsins kom fram að heimilt væri að framselja aflahlutdeild í flokki 1 milli skipa fyrstu 20 árin eftir útgáfu nýtingarleyfis. Við pað hefði hlutdeildin hins vegar skerst um 3\%. Skv. 4. mgr. 12. gr. frumvarpsins var framsal aflahlutdeilda óheimilt eftir að 20 ára tímabilið er liðið. Ekki eru í frumvarpinu færð rök fyrir peirri lokun á flokki 1.

\subsubsection{Flokkur 2}

Með nýjum flokki aflahlutdeilda í ríkisforsjá (flokkur 2) var m.a. stefnt að pví að ná inn nokkurri auðlindarentu og auka möguleika á nýliðun (Pingskjal 1052, 2011-2012, athugasemdir, kaflar 2.8.-2.10.). Pá átti með „pessari verulegu aukningu aflahlutdeildar ráðherra og auknum sveigjanleika til úthlutunar [að] leitast við að draga úr óvissu og auka stöðugleika peirra byggða sem veikast standa." (Pingskjal 1052, 2011-2012, athugasemdir, kafli 2.9.). Í flokk 2 átti samkvæmt 20. og 24. gr. frumvarpsins að fella allan pann hluta heildaraflans sem ráðherra hefur í dag til ráđstöfunar í sérgreindum tilgangi s.s. í formi byggðakvóta og línuívilnunar, sbr. 3. til 5. mgr. 8. gr. laga nr. 116/2006. Auk pess átti að skerða aflahlutdeildir skipa um ákveðið hlutfall í upphafi fiskveiðiárs 2012/2013 og fella pær í flokk 2, sbr. bráðabirgðaákvæði II og VII. Samtals var gert ráð fyrir að um $6.6 \%$ heildaraflahlutdeilda yrðu í flokki 2 í upphafi (Pingskjal 1052, 2011-2012, athugasemdir, kafli 2.9). Auk pess áttu í framtíðinni að koma til frekari skerðingar á flokki 1 sem áttu að renna í flokk 2, sbr. ákvæði 2. mgr. 13. gr. um 3\% skerðingu aflahlutdeild í flokki 1 við framsal peirra. Samkvæmt pessu gerði frumvarpið ráð fyrir að flokkur 2 myndi vaxa smám saman en flokkur 1 minnka. 
Ráðherra var í 1. mgr. 18. gr. frumvarpsins falið að ráðstafa aflamarki sem tilheyrði flokki 2 á kvótapingi, skv. heimild í 19. gr., eða til sértækra ráðstafana skv. heimild í 20.-24. gr., sbr. 1. mgr. 18. gr. frumvarpsins. Skv. 2. málsl. 19. gr. var ráðherra falin mjög óljóst orðuð heimild til að binda ráðstöfun aflamarks á kvótapingi við útgerðir sem væru staðsettar á „tilteknum svæðum að bundnum nánari skilyrðum.“ Pá var ráðherra heimilt frá og með fiskveiðiárinu 2015/2016 að framselja aflahlutdeild í flokki 2 til að stuðla að nýliðun með útgáfu nýrra nýtingarleyfa. Leyfin átti annað hvort að bjóða út eða binda pau við svæði sem hallaði á í atvinnu- og byggðarlegu tilliti, sbr. 2. mgr. 18. gr. Í frumvarpinu var ekki mælt fyrir um hversu stórum hluta árlegra veiðiheimilda sem félli í flokk 2 ætti að ráðstafa á kvótapingi eða hve miklu magni aflahlutdeilda ráðherra væri heimilt að ráðstafa. Pá var ráðherra veitt mikið svigrúm til mats um pað hvernig aflamarki skyldi ráðstafað á kvótapingi og hvort aflahlutdeildum yrði ráðstafað til nýliðunar eða til sértækra byggðaráðstafana. Gefur frumvarpið pví afar óljósa mynd af pví hversu mikið magn aflahlutdeilda eða aflamarks sem tilheyrði flokki 2 gat staðið öllum til boða.

\subsection{Mat á jafnræði}

Við mat á pví hvort aflamarkskerfið eins og pað var útfært í frumvarpinu samræmist jafnræðisreglu 65. gr. stjskr. og meðalhófssjónarmiðum sem hún byggir á er litið til peirrar leiðbeiningar sem dregin var af dómum Hæstaréttar í kafla 4. Umfjölluninni verður skipt í tvo megin hluta. Annars vegar um úthlutun nýtingarleyfa í upphafi og hins vegar um nánari útfærslu kerfisins.

\subsubsection{Forsendur við val á peim sem fá nýtingarleyfi í upphafi}

Skv. 11. gr. frumvarpsins gátu eigendur peirra skipa sem höfðu yfir að ráða aflahlutdeild pegar frumvarpið varð að lögum eða fengu aflahlutdeild framselda til sín sótt um nýtingarleyfi. Samkvæmt pví gerði frumvarpið ráð fyrir að hópur peirra sem réði yfir aflahlutdeild yrði í upphafi afmarkaður með sama hætti og í gildandi kerfi. Nýtingarleyfi átti að gefa út á eigendur skipa og var óheimilt að framselja pau, sbr. 2. mgr. 11. gr. Aflahlutdeild peirra útgerðaraðila sem ekki höfðu fengið slíkt leyfi um áramótin 2012/2013 átti að færast í flokk 2. Nýtingarleyfi var pví skv. frumvarpinu skilyrði pess að útgerðir héldu aflahlutdeild sinni. Ekki verður annað séð en að regla 11. gr. frumvarpsins byggi á sömu sjónarmiðum og Hæstiréttur hefur viðurkennt að séu málefnaleg, p.e. að miðað sé við hagsmuni af atvinnu og fjárfestingum sem hafa verið bundin sjávarútvegi og reynslu og pekkingu pví samfara (Vatneyrardómurinn og mál Elínar $\mathrm{PH} 85)$.

Kæmi til aflatakmarkana í nýjum tegundum átti skv. 9. gr. frumvarpsins að fjalla um úthlutun aflahlutdeildar í sérstökum lögum. Ráðherra var falið mat um pað hvenær skyldi leggja fram frumvarp til laga um úthlutun aflahlutdeilda. Honum var hins vegar gert að leggja ákveðnar forsendur til grundvallar tillögum um úthlutun aflahlutdeildar. Var ráðherra gert að taka mið af veiðireynslu, bæði fyrir og eftir gildistöku laganna, réttmætum hagsmunum peirra sem hófu veiðar, verðmætamyndun og heildarmarkmiðum laganna. 
Pessar forsendur höfðu pó takmarkaða pýðingu par sem löggjafinn hefði að sjálfsögðu ekki verið bundinn af peim. Hér verður pví látið nægja að benda á að sumar peirra virðast mjög almennar og matskenndar og kunna af peim sökum að orka tvímælis. Pannig verður t.d. ekki séð hvernig almenn tilvísun til óskilgreindra heildarmarkmiða laga geti veitt leiðbeiningu um hvernig skipta skuli heildarafla á milli skipa. Af ofansögðu verður ekki annað ráðið en að í frumvarpinu felist að löggjafinn muni taka afstöðu til pess á hvaða sjónarmiðum verður byggt við úthlutun nýrra tegunda. Er val hans takmarkað af pví að sjónarmiðin sem lögð eru til grundvallar verða að vera málefnaleg (Vatneyrardómur).

\subsubsection{Er eðlilegt jafnvægi milli peirrar leiðar sem valin er við útfærslu nýtingarréttarins og peirra markmiða sem stefnt er að?}

Út frá sjónarmiðum um atvinnufrelsi og jafnræði skiptir máli að takmörkun á gildistíma nýtingarréttar getur verið til pess fallin að fleiri eigi pess kost að fá aðgang að veiðum. •að er pó auðvitað háð pví til hve langs tíma rétturinn er og á hvaða forsendum ný úthlutun fer fram.

Samkvæmt frumvarpinu áttu nýtingarleyfi að gilda í a.m.k. 20 ár frá upphafi fiskveiðiárs 2012. Óljóst er eins og áđur segir á hvaða forsendum gildistíminn byggði. Pó virðist mega ráđa að einkum hafi átt að taka tillit til stjórnarskrárvarinna atvinnuréttinda peirra sem pegar lögðu stund á veiðar. Álitaefni um hvort nægilegt tillit er tekið til slíkra réttinda fellur utan við efnissvið greinarinnar. Af áður tilvitnaðri dómaframkvæmd Hæstaréttar um úthlutun aflahlutdeildar má pó álykta að málefnalegt er að leggja pessi sjónarmið til grundvallar við ákvörðun á gildistíma nýtingarleyfa.

Erfitt er að leggja mat á pað hvort aðgangur að fiskveiðum á pessu 20 ára tímabili hefði orðið rýmri eða prengri en samkvæmt gildandi kerfi. Peir sem ekki höfðu yfir að ráða aflahlutdeild eða vildu auka við hana áttu líkt og í gildandi kerfi kost á pví að kaupa aflahlutdeild í flokki 1. Pá áttu peir pess einnig kost að kaupa aflamark á kvótapingi. Sú 3\% skerðing sem gert var ráð fyrir að yrði á aflahlutdeild við framsal milli skipa og takmarkanir á rétti útgerða til að framselja aflamark hefðu pó getað dregið úr framboði veiðiheimilda (Daði Már Kristófersson og Póroddur Bjarnason, 2012, III. kafli). Framboð veiðiheimilda í flokki 2 hefði getað vegið á móti pessu. Par sem ekki er ljóst hversu stór flokkur 2 hefði getað orðið á pessum tíma og vegna pess mikla svigrúms sem ráðherra var fengið við ráðstöfun heimildanna er erfitt að segja til um hvort sú hefði orðið raunin. •að er pví mjög háð framkvæmd löggjafarinnar hvort kerfið samræmist reglum stjórnarskrárinnar um jafnræði.

Í frumvarpinu var gert ráð fyrir að breytt kerfi tæki við að liðnum 20 árum. Pað var háð pví hvort ráðherra tilkynnti um brottfall nýtingarleyfis með 15 ára fyrirvara hvernig pað kerfi hefði orðið. Sendi ráðherra slíka tilkynningu og staðfesti Alpingi hana með pingsályktunartillögu var gert ráð fyrir að aflahlutdeildir í flokki 1 féllu allar niður við lok gildistímans (p.e. árið 2032). Óljóst var hvað pá átti að taka við. Sendi ráðherra hins vegar ekki slíka tilkynningu hefðu nýtingarleyfishafar áfram haldið aflahlutdeildum í flokki 1. Par 
sem aflahlutdeildir áttu ekki að vera framseljanlegar á framlengingartímanum hefði hópur peirra sem yfir slíkum heimildum réði pví væntanlega lokast og aðrir ekki átt pess kost að komast í sömu stöðu. Af frumvarpinu virðist mega ráða að peir sem ekki réðu yfir aflahlutdeild í flokki 1 hefðu verið háðir kaupum á aflamarki á kvótapingi eða sértækum ráðstöfunum ráðherra og ekki notið pess fyrirsjáanleika í rekstri sem 15 ára tilkynningarfrestur átti skv. frumvarpinu að tryggja. Staða peirra hefði að pví leyti verið mun lakari en peirra sem réðu yfir aflahlutdeildum í flokki 1. Í frumvarpinu eða öðrum lögskýringargögnum er ekki að finna skýringar á pví á hvaða rökum petta fyrirkomulag var reist eða hvernig pað samræmdist markmiðum laganna. Рað er pví óvíst að pessar tillögur í frumvarpinu hefðu samræmst jafnræðisreglu 65. gr. stjskr. og 75. gr. hennar.

\section{Niðurstöður og lokaorð}

Vandasamt er að draga almennar ályktanir út frá réttarframkvæmd um hvernig svigrúm löggjafans er afmarkað skv. jafnræðisreglu 65. gr. stjskr. og peim jafnræðissjónarmiðum sem 75. gr. stjskr hvílir á. Svigrúmið markast af atvikum máls, s.s. pví hversu rík takmörkun er, en einnig af pví hvaða inntak og vægi markmiðum laga er gefið. Í pví sambandi virðist nálgun Hæstaréttar við skýringu á inntaki sameignarhugtaks 1. gr. laga nr. 116/2006 hafa skipt máli. Pó má draga pá almennu ályktun að Hæstiréttur leggi pað til grundvallar við meðalhófsmatið að löggjafanum beri að stjórna fiskveiðum með hagsmuni pjóðarheildarinnar að leiðarljósi og að löggjafinn verði pví ávallt að færa skýr rök fyrir pví að ráðstafanir sem takmarka aðgang manna að veiðum og gera upp á milli peirra samræmist hagsmunum pjóðarheildarinnar. Hæstiréttur virðist meta hvort slík rök liggi fyrir og kann að telja slíkar ráðstafanir ónauðsynlegar ef samræmið er óljóst. Sé frumvarp til laga um stjórn fiskveiða skoðað með hliðsjón af pessum sjónarmiðum eru pað einkum forsendur framlengingar nýtingarleyfis og pað fyrirkomulag sem gert var ráð fyrir að tæki við pegar 20 ára aðlögunartímabili að nýju kerfi lyki sem vekur spurningar. Óljóst er á hvaða forsendum framlenging nýtingarleyfis átti að byggja. Hins vegar er ljóst að til hefði orðið lokað kerfi aflahlutdeilda sem veitt hefði afmörkuðum hópi rétt til úthlutunar aflamarks sem aðrir hefðu ekki getað notið. Ekki voru færð fram efnisleg rök fyrir pessu fyrirkomulagi og hvernig pað átti að pjóna heildarhagsmunum pjóðarinnar. Af peim sökum er vafasamt að pað hefði samrýmst jafnræðisreglu 65. gr. og jafnræðissjónarmiðum 75. gr. stjskr. 


\section{Heimildaskrá}

Alpjóðasamningur um borgaraleg og stjórnmálaleg réttindi (International Covenant on Civil and Political Rights). 26. gr. (Sampykktur 16. desember 1966, tók gildi 23. mars 1976). 999 U.N.T.S 171.

Álit MNSP 24. október 2007 í máli nr. 1306/2004. Erlingur Sveinn Haraldsson og Örn Snævar Sveinsson gegn Íslandi. CCPR/C/91/D/1306/2004.

Björg Thorarensen. (2008). Stjórnskipunarréttur: Mannréttindi. Codex.

Björg Thorarensen. (2003). Áhrif meðalhófsreglu við skýringu stjórnarskrárákvæða (bls. 51105). Í Ari Karlsson o.fl. (ritstj.) Lögberg. Rit Lagastofnunar Háskóla Íslands. Háskólaútgáfan.

Daði Már Kristófersson og Póroddur Bjarnason. (2012). Greinargerð um frumvarp til laga um stjórn fiskveiða og frumvarp til laga um veiðigjald, 22. mars 2012. Pingskjal 1052. (2011-2012) Frumvarp til laga um stjórn fiskveiða. Alpingistíðindi A-deild. 140. Fylgiskjal I. Sótt 13. ágúst 2012 af http://www.althingi.is/altext/140/s/1052.html.

Gaukur Jörundsson. (1969). Eignarnám. Bókaaútgáfa Menningarsjóðs.

Guðrún Gauksdóttir (2006). Eru aflaheimildir eign í skilningi 72. gr. stjskr. Í Pétur Kr. Hafstein o.fl. Guðrúnarbók: Afmælisrit til heiðurs Guðrúnu Erlendsdóttir 3. maí 2006. (Bls. 249275). Hið íslenska bókmenntafélag.

Hafréttarsamningur Sameinuðu pjóðanna (UN Convention on the Law of the Sea) (Sampykktur 10. desember 1982, gekk í gildi 16. nóvember 1994). 1833. U.N.T.S. 397.

Helgi Áss Grétarsson. (2008) Úthlutun porskveiðiheimilda 1984-2007: lagalegar staðreyndir eða staðalímyndir? Í María Tehjll (ritstj.). Afmælisrit lagadeildar Háskóla Íslands. (Bls. 229-297). Codex.

Helgi Áss Grétarsson. (2011) Djóðin og kvótinn: Um íslenska fiskveiðistjórnunarkerfið 1991-2010 og stjórnskipuleg álitaefni. Lagastofnun Háskóla Íslands.

Hrd. 3. desember 1998 í máli nr. 145/1998. Valdemar Jóhannesson gegn íslenska ríkinu.

Hrd. 21. október 1999 í máli nr. 157/1999. Ákæruvaldið gegn Vilhjálmi Birgissyni.

Hrd. 6. apríl 2000 í máli nr. 12/2000. Ákæruvaldið gegn Birni Kristjánssyni, Svavari Rúnari Guðnasyni og Hyrno ehf.

Hrd. 20. mars 2003 í máli nr. 473/2002. Ákæruvaldið gegn Erlingi Sveini Haraldssyni, Erni Snævari Sveinssyni og Fagramúla ehf.

Hrd. 24. apríl 2005 í máli nr. 455/2004. Ákæruvaldið gegn Birni Guðna Guðjónssyni. 
Hrd. 18. nóvember 2004 í máli nr. 221/2004. Íslenska ríkið gegn Loðnuvinnslunni hf og gagnsök

Hrd. 6. apríl 2006 í máli nr. 220/2005. JT International S.A. o.fl. gegn íslenska ríkinu og gagnsök.

Hrd. 27. september 2007 í máli nr. 182/2007. Björgun ehf. gegn íslenska ríkinu.

Hrd. 19. mars 2009 í máli nr. 425/2009. Dagbjartur Bogi Ingimundarson og Rafn Ingimundarson gegn Norðurpingi og Vegargerðinni.

Hrd. 3. desember 2009 í máli nr. 121/2009. Elín PH-82 gegn íslenska ríkinu.

Hrd. 19. janúar 2012 í máli nr. 443/2011. Sigurbjörn ehf. gegn íslenska ríkinu.

Karl Axelsson. (2000) Vatneyrardómur: Um dóm Hæstaréttar frá 6. apríl 2000 í málinu nr. 12/2000. Úlfljótur 53(2), 270-274.

Karl Axelsson og Lúðvík Bergvinsson. (2010). Minnisblað til starfshóps um endurskoðun laga um fiskveiðistjórnun. Í Skýrsla starfshóps um endurskoðun á lögum um stjórn fiskveiða. Álitamál, greiningar, skýrslur og valkostir við breytingar á stjórn fiskveiða, Sjávarútvegs- og landbúnaðarráðuneytið. Fylgiskjal 3.

Mannréttindanefnd Sameinuðu pjóðanna. Álit 14. desember 2007 í máli nr. 1306/2004, Haraldson and Sveinsson v. Iceland. UN Doc. CCPR/C/91/1306/2004.

MDE, 23. júlí 1968, Belgian Linguistics, Series A, Vol. 6.

Oddný Mjöll Arnardóttir. (2000). Vatneyrardómurinn í ljósi tilgátu um samspil jafnræðisreglunnar og endurskoðunarvalds dómstóla. Úlfljótur 53(2) 2, 276-281.

Oddný Mjöll Arnardóttir. (2005). Bann við mismunun. Í Björg Thorarensen o.fl. (ritstj.) Mannréttindasáttmáli Evrópu: Meginreglur, framkvæmd og áhrif á íslenskan rétt (bls. 433- 473). Mannréttindastofnun Háskóla Íslands og Lagadeild Háskólans í Reykjavík.

Páll Hreinsson. (2002). Litróf jafnræðisreglna. Í Ármann Snævarr o.fl. (ritstj.), Afmælisrit til heiðurs Gunnari G. Schram sjötugum 20. febrúar 2001 (bls. 503-533). Almenna bókafélagið.

Samningur um verndun mannréttinda og mannfrelsis - Mannréttindasáttmáli Evrópu (European Convention for the protection of Human Rights and Fundamental Freedoms). (Sampykktur 4. nóvember 1950, tók gildi 3. september 1953). 213 U.N.T.S. 221.

Seibert-Fohr, A. (2010). The rise of Equality in International Law and its Pitsfalls: Learning from Comparative Constitutional Law. Brooklin Journal of International Law 35(1), 2-39.

Sigurður Líndal. (2000). Vatneyrardómur: Hæstiréttur og stjórn fiskveiða. Úlfljótur 53(2), 283-300. 
Sigurður Líndal. (2012). Hugtakið pjóðareign. Úlfljótur, 65(1) 101-125.

Sjávarútvegsráđuneytið. (1993). Skýrsla nefndar um mótun sjávarútvegsstefnu. Pingskjal 360 (1993-1994). Alpingistíđindi A-deild, 117. Frumvarpi til laga um breytingu á lögum nr. 3815. maí 1990, um stjórn fiskveiða, fylgiskjal II.

Sjávarútvegsráðuneytið. (2001). Skýrsla nefndar um endurskoðun laga um stjórn fiskveiða. Sótt 1. ágúst 2012 á http://www.atvinnuvegaraduneyti.is/utgafa/utgefid-efni/eldraefni/sjr/nr/3971 sótt á vef Sjávarútvegs- og landbúnaðarráðuneytið. (2010).

Sjávarútvegs- og landbúnaðaráðuneytið (2010). Skýrsla starfshóps um endurskoðun á lögum um stjórn fiskveiða. Álitamál, greiningar, skýrslur og valkostir við breytingar á stjórn fiskveiða. Sótt 1. ágúst 2012 á http://www.atvinnuvegaraduneyti.is/utgafa/utgefid-efni/eldraefni/sjrland/nr/5387.

Skúli Magnússon. (2000). Óleyst álitaefni og fræðileg vonbrigði. úlfljótur 53(4), 643-651.

Skúli Magnússon. (2011). Stjórnarskrárákvæði um auðlindir - lögfræðileg álitaefni. (Bls. 225248, 1. bindi). Í Guðrún Pétursdóttir (ritstj.) Skýrsla stjórnlaganefndar (Stjórnlaganefnd, 2011).

Stjórnlagaráð. (2011) Frumvarp til stjórnarskipunarlaga. Sótt 3. september 2012 á http://www.stjornlagarad.is/other_files//stjornlagarad/Frumvarp-tilstjornarskipunarlaga.pdf.

Utanríkisráðuneytið. (2012). Fréttatilkynning 5. júní 2012. Sótt 10. ágúst 2012 á http://www.utanrikisraduneyti.is/frettir/nr/7087.

Pingskjal 1052. ( 2011-2012). Frumvarp til laga um stjórn fiskveiða. Alpingistíðindi A-deild, 140. Sótt 13. ágúst 2012 af http://www.althingi.is/altext/140/s/1052.html

Pingskjal 1053. (2011-2012). Frumvarp til laga um veiðigjöld. Alpingistíðindi A-deild, 140. Sótt 13. ágúst 2012 af http://www.althingi.is/altext/140/s/1053.html.

Pingskjal 389. (1994-1995). Frumvarp til stjórnarskipunarlaga. Alpingistíđindi A-deild, 118.

Sótt 15. ágúst 2012 af http://www.althingi.is/altext/118/s/0389.html

Pingskjal 1059. (1989-1990). Frumvarp til laga um stjórn fiskveiða. Alpingistíðindi A-deild, 112. Sótt 15. ágúst 2012 af http://www.althingi.is/altext/118/s/0389.html

Porgeir Örlygsson. (1998) Hver á kvótann? Tímarit lögfræðinga, 48(1), 28-59. 